\title{
El català com a aliat contra la soledat
}

\author{
Selçuk-Destan Türkaslan \\ Humboldt-Universität zu Berlin
}

Rebut: 21 de febrer de 2021

Acceptat: 28 de febrer de 2021

Era una tarda plujosa i freda de novembre, a la petitíssima cambra que jo habitava. El sol es posava a la finestra i la seva dimensió tapava el reflex de mon rostre. Tenia divuit anys i me n'havia anat a Tenerife per unes pràctiques en un parc cultural que es deia Mariposa. La idea d'anar-hi no era meva, jo només volia acompanyar una amiga de l'institut. Abans d'anar-hi, somiava amb el sol, amistats noves i potser fins i tot un amor nou. La realitat, però, seria molt més desencisant: vet-me aquí, damunt d'una muntanya, en un poblet de mala mort que les mateixes deesses i déus havien oblidat, sofrint els devessalls que em van deixar sense connexió.

Un dia d'aquests, en aquella cambra petitíssima, vaig recordar-me del català. Hi havia una llengua a la península Ibèrica totalment desconeguda per a mi que em semblava mitològica: tota una societat, una cultura, una llengua esperant-me! Tanmateix, em posí a la recerca, i, tatxan!, vaig trobar tot un món per a fugir de la monotonia i l'aillament. Descobrí, en particular, les cançons de Guillermina Motta. No és que les entengués, però en gaudia mentre escombrava arreu del parc o feia la bugada. Em balandrejava al compàs, passant la baieta per una superfície: Si soc tan sols un tros de terra, per què sento un anhel d'eternitat? Agafava l'escombra, llançant-me a la dreta -com que soc molt eixerida com hi ha món-i giravoltava cap a l'esquerra -ja he après l'enraonar d'allà a London. És clar, la meva productivitat sofrí una mica, però jo no; jo continuava ballant, cantant, sentint els sentiments de cada cançó i cadència amb delit.

És clar que després aní a Barcelona per a veure la ciutat. El meu castellà havia millorat, tot i que ja no era una prioritat. Em posí a buscar llibres de català i, mare meva, n'hi havia massa! Català 1.1, Català 1.1b, Català 1.1b-i-una-miqueta-més -i eren caríssims! Vaig buscar-ne també d'ocasió, però no trobí pas res. Així m'oblidí del català, m'avorrí de la Guillermina Motta...

Fins un dia en el qual descobrí un país: benvinguda a ma vida, Andorra! D'aquí, una porta de recerca obrí l'altra: occità antic, català septentrional, valencià, alguerès; la Universitat Oberta de Catalunya; Mercè Rodoreda, Maria-Mercè Marçal, Clementina Arderiu...

A la fi, tot em dugué a les meravelloses classes de llengua i cultura catalanes de la Universitat Humboldt de Berlín. Hi aprenguí una altra cultura, llengua, i forma de pensar i viure. M'enamorí de la Montserrat Roig, assistí a xerrades - per Zoom, és clar- amb directors de pel-lícules com la Neus Ballús o en Carles Bover. Una altra vegada, el català va resultar ser un refugi de l'aillament.

Hi ha, però, moltes fitxes i quaderns de vocabulari a la meva vida. Podcasts com Oye Polo, pel-lícules i sèries catalanes a Netflix, llibres i poemes... Segueixo pàgines a Instagram amb mems catalans o valencians, soc a servidors catalans a Discord... Faig fins i tot soliloquis 
catalans a casa per a descobrir els temes que encara no sé com expressar! Tant em fa semblar una mica boig, el català em sembla tan divertit i eufònic que no em cansa haver de seguir aprenent per a retenir-lo. I a la fi, aprendre el català obre portes! Fa poc, vaig assistir a un taller de lector editorial a Alemanya, ofert per l'Institut Ramon Llull; llegir tot el dia no és feina, és un somni -un somni sense diners, però així i tot un somni.

Després dels meus estudis de grau, vull anar a viure a Barcelona, tenir amigues i amics catalanoparlants i fer el meu màster a la Universitat Pompeu Fabra. Aquest cop, no penso oblidar el català. Aquest cop, m'esforçaré cada dia més per a integrar-lo a ma vida. Propera parada: Universitat Pompeu Fabra! 